\title{
Contribution of neural intrapancreatic non-cholinergic non-adrenergic mechanisms to glucose-induced insulin release in the isolated rat pancreas
}

\author{
N. Weigert, M.Dollinger, R. Schmid and V.Schusdziarra \\ Department of Internal Medicine II, Technical University of Munich, FRG
}

\begin{abstract}
Summary. In the isolated rat pancreas the effect of intrapancreatic non-adrenergic non-cholinergic nerves was examined upon insulin, glucagon and somatostatin release during perturbations of perfusate glucose. Elevation of glucose from 1.6 to $8.3 \mathrm{mmol} / \mathrm{l}$ increased insulin and somatostatin secretion and inhibited glucagon release. The first phase of insulin secretion was significantly reduced by the neurotoxin tetrodotoxin to $55 \%$ of the controls $(p<0.05)$. The somatostatin response was attenuated by tetrodotoxin while the change of glucagon remained unaffected. In contrast the combined adrenergic and cholinergic blockade with atropine, phentolamine and propranolol $\left(10^{-5} \mathrm{~mol} / \mathrm{l}\right)$ did not modify the insulin, glucagon and somatostatin response. When glucose was changed from 8.3 to $1.6 \mathrm{mmol} / 1$, the reduction of insulin and somatostatin release was not modified by tetrodotoxin, but stimulation of glucagon was significantly attenuated by $60-70 \%(p<0.03)$, which was similar to the effect of combined adrenergic and cholinergic blockade. Subsequently, the effect of neural blockade was examined during more
\end{abstract}

physiological perturbations of perfusate glucose levels. When glucose was changed from 3.9 to $7.2 \mathrm{mmol} / \mathrm{l}$, tetrodotoxin also attenuated first phase insulin response by $40 \%$ while cholinergic and adrenergic blockade had no effect. The nitric oxide synthase inhibitor $\mathrm{N}^{\mathrm{G}}$-Nitro-L-arginine-methylester (L-NAME) did not alter the glucose-induced insulin response indicating that nitric oxide is not involved in this mechanism. It is concluded that neural non-adrenergic noncholinergic mechanisms contribute to the first, but not second phase of glucose-induced insulin release. Non-adrenergic non-cholinergic effects do not participate in regulation of glucagon and somatostatin secretion under the conditions employed. The non-adrenergic non-cholinergic effect is most likely of peptidergic nature and remains to be examined in greater detail.

Key words: Intrinsic nerves, isolated rat pancreas, insulin, somatostatin, glucagon, glucose, adrenergic, cholinergic.
The islets of Langerhans are complex functional units composed of endocrine cells which are supplied by blood vessels and autonomic nerves [1]. The pancreas receives an abundant supply of extrinsic autonomic nerves from the vagal trunks and the splanchnic nerves [2]. Apart from this extrinsic nervous system the pancreas contains intrinsic neurons, which form periinsular, periacinar, and perivascularplexuses which are connected with one another and with intrapancreatic ganglia [3]. These intrapancreatic neurons are still observed after extrinsic denervation $[4,5]$.

This morphological relationship makes it likely that nerves are involved in the physiological regulation of islet function. The participation of the adrenergic and cholinergic nervous system is fairly well documented and has been summarized previously [2, 6-10]. On the other hand, the contribution of the intrinsic nervous elements is largely unknown. In a classical approach Hisatomi et al. [11] have shown that adrenergic fibres of the intrinsic system are important for regulation of A-cell function while they do not contribute to insulin and somatostatin release.

Apart from the classical neurotransmitters many different peptides have been localized in nerve terminals throughout the pancreas such as cholecystokinin (CCK) [12, 13], calcitonin gene-related peptide (CGRP) [14], met-enkephalin and leu-enkephalin [12,15], galanin [16], gastrin-releasing peptide (GRP) and bombesin-like immunoreactivity [17], neuropeptide Y (NPY) [18], PHI $[19]$, substance $P[12,20]$ and vasoactive intestinal polypeptide (VIP) $[12,19]$. All these neuropeptides can influence islet hormone secretion, when they are infused in vivo or in vitro [6]. This and the morphological data raise the possibility of a functional role of these neuropeptides in islet cell hormone secretion.

For the vast majority of neuropeptides specific receptor antagonists are not available to examine their biological role. Therefore, we have employed the neurotoxin te- 
trodotoxin (TTX) which blocks all neural elements that are activated by an influx of $\mathrm{Na}^{+}$. This comprises all the adrenergic and cholinergic neurons and presumably the majority of peptidergic neurons as well [21-23]. Cholinergic and adrenergic neurons were antagonized by the respective specific blocking agents [7]. From the difference in these effects, the potential involvement of the peptidergic system was deduced.

Accordingly, the influence of intrapancreatic nonadrenergic non-cholinergic neural elements on insulin, glucagon and somatostatin secretion during perturbations of perfusate glucose levels was examined in the isolated perfused rat pancreas.

\section{Materials and methods}

The experiments were performed in an isolated rat pancreas preparation according to the detailed description of Sussman et al. [24]. After an overnight fast, male Wistar rats (body weight 300-350 g, Charles River Wiga GmbH, Sulzfelden,FRG) were anaesthetized (pentobarbital sodium, $60 \mathrm{mg} / \mathrm{kg}$ i.p.; Rhone-Merieux, Köln, FRG).Pancreata were isolated and placed in an organ bath at $37^{\circ} \mathrm{C}$ and perfused through the celiac and mesenteric artery in a single pass perfusion system at a constant flow rate of $2 \mathrm{ml} / \mathrm{min}$ as described previously [25].

The perfusion medium consisted of a Krebs-Ringer buffer solution containing $4 \%$ dextran T70 (Pharmacia, Uppsala, Sweden) and $0.2 \%$ human serum albumin (Behring, Marburg, FRG). In the first series of experiments the perfusate glucose concentrations were changed between $1.6 \mathrm{mmol} / \mathrm{l}(30 \mathrm{mg} / \mathrm{dl})$ and $8.3 \mathrm{mmol} / \mathrm{l}(150 \mathrm{mg} / \mathrm{dl})$. In a subsequent experimental group more physiological perturbations of perfusate glucose between 3.9 and $7.2 \mathrm{mmol} / \mathrm{l}$ (70 and $130 \mathrm{mg} / \mathrm{dl}$ ) were employed. The perfusate was gassed with $95 \% \mathrm{O}_{2}$ and $5 \% \mathrm{CO}_{2}$ and the $\mathrm{pH}$ was maintained between 7.35 and 7.45 . The pancreatic venous effluent was collected via a catheter in the portal vein at 1-min intervals and frozen immediately for subsequent radioimmunoassays.

For equilibration after the end of surgery, the pancreas was perfused for 20 min with buffer containing the glucose concentration of the initial 10-min experimental basal period. Thereafter the glucose concentration was elevated or reduced for 20 min which was followed by another 20-min period with perfusate glucose levels of the basal period.

For neural blockade either a combination of $10^{-5} \mathrm{~mol} / 1$ atropine sulphate (Sigma, München, FRG), $10^{-5} \mathrm{~mol} / \mathrm{l}$ phentolamine (Ciba, Basel, Switzerland) and $10^{-5} \mathrm{~mol} / 1$ propranolol (Rhein-Pharma, Heidelberg, FRG), or the neurotoxin TTX $\left(10^{-6} \mathrm{~mol} / \mathrm{l}\right.$, Sigma) was added during the entire experimental period. For blockade of nitric oxide synthase $\mathrm{N}^{\mathrm{G}}$-Nitro-L-arginine-methylester (L-NAME; Sigma) was added to the perfusate at $10^{-4} \mathrm{~mol} / \mathrm{l}$, a concentration which has recently been shown to be effective [26].

In controls the pancreas was perfused at a constant glucose concentration of 1.6 or $8.3 \mathrm{mmol} / \mathrm{l}$ with and without the neuronal blocking agents atropine, phentolamine and propranolol or the neurotoxin TTX, respectively. In each pancreas only one experiment was performed.

Perfusate insulin [27], glucagon [28] and somatostatin [29] were determined radioimmunologically as described elsewhere. Antibody $30 \mathrm{~K}$ for glucagon measurements and antibody $80 \mathrm{C}$ for somatostatin measurements were generously provided by Dr. R.H. Unger (Dallas, Texas, USA). For insulin determination a commercially available insulin-kit (IDW, Frankfurt, FRG) was employed.

\section{Statistical analysis}

All data are expressed as mean $\pm S E M$. Integrated hormone secretion was calculated as the sum of the differences between each point during stimulation and the mean value of the preceding baseline period. Minute-to-minute variations were evaluated by the use of the Friedman two-way analysis of variance, followed by the Wilcoxon matched-pairs signed rank test if the former allowed rejection of the null hypothesis. The difference of integrated values between treatment groups was analysed by analysis of variance for multiple determinations. Differences resulting in $p$-values of 0.05 or less were considered significant.

\section{Results}

\section{Effect of TTX}

The elevation of the perfusate glucose concentration from 1.6 to $8.3 \mathrm{mmol} / \mathrm{l}$ (Fig. 1) elicited a rise of perfusate insulin levels from $36 \pm 7 \mathrm{pmol} / 1$ to a maximum of $427 \pm 79 \mathrm{pmol} / 1$ within $5 \mathrm{~min}$. Thereafter insulin decreased during the ensuing $5 \mathrm{~min}$ to $188 \pm 29 \mathrm{pmol} / \mathrm{l}$ and increased again in a second phase to $297 \pm 43 \mathrm{pmol} / \mathrm{l}$. When the glucose level was restored to $1.6 \mathrm{mmol} / 1$, insulin levels promptly returned to basal values.

The addition of the neurotoxin TTX $\left(10^{-6} \mathrm{~mol} / \mathrm{l}\right)$ to the perfusate resulted in a significant reduction of the insulin peak during the first phase of glucose-induced insulin secretion $(427 \pm 79 \mathrm{pmol}$ in the controls vs $224 \pm 43 \mathrm{pmol} / 1$ during TTX, $p<0.03$ ) (Fig.1). Additionally the integrated insulin response to the first $10 \mathrm{~min}$ of high glucose was significantly lower than in the controls $(4026 \pm 876 \mathrm{pmol} /$ $10 \mathrm{~min}$ in the controls vs $2041 \pm 304 \mathrm{pmol} / 10$ min during TTX, $p<0.03$ ). The second phase insulin secretion was similar in both groups.

Perfusate somatostatin levels rose after the elevation of the glucose concentration from a mean baseline of $34 \pm 7$ to a maximal level of $77 \pm 11 \mathrm{ng} / \mathrm{l}(p<0.01)$ and returned to basal values thereafter. TTX attenuated the rise of somatostatin significantly. The integrated somatostatin level during the first $10 \mathrm{~min}$ of high glucose was $283 \pm 46 \mathrm{ng} / \mathrm{l}$ in the controls and only $65 \pm 40 \mathrm{ng} / \mathrm{l}$ $(p<0.03)$ in the presence of TTX (Fig. 1 A).

Glucagon secretion was suppressed during the phase of elevated glucose from $302 \pm 42$ to $90 \pm 7 \mathrm{ng} / 1(p<0.01)$ and rose again to $283 \pm 58 \mathrm{ng} / \mathrm{l}$ when the perfusate glucose concentration had been reduced to $1.6 \mathrm{mmol} / \mathrm{l}$. TTX had no effect on glucose-induced suppression of glucagon secretion. However, the rebound during the subsequent phase of low perfusate glucose was significantly attenuated by TTX (Fig. 1A). The incremental glucagon release between 30 and $50 \mathrm{~min}$ was $2439 \pm 650 \mathrm{ng} / 20 \mathrm{~min}$ in the controls and only $857 \pm 123 \mathrm{ng} / 20 \mathrm{~min}$ with TTX $(p<0.01)$.

When the perfusate glucose concentration was first decreased from 8.3 to $1.6 \mathrm{mmol} / 1$ and then increased again to $8.3 \mathrm{mmol} / \mathrm{l}$, insulin secretion was almost completely suppressed during the period of glucopoenia. After elevation of the glucose concentration insulin was stimulated in a biphasic pattern with a maximum of $594 \pm 50 \mathrm{pmol} / 1$ during the first and $391 \pm 72 \mathrm{pmol} / 1$ during the second phase (Fig.2).

TTX did not modify the suppression of insulin release by glucopoenia (Fig. $2 \mathrm{~A}$ ), but reduced significantly the maximal (594 \pm 50 vs $268 \pm 87 \mathrm{pmol} / 1, p<0.01)$ and the integrated (3794 \pm 535 vs $1919 \pm 369 \mathrm{pmol} / 10 \mathrm{~min}, p<0.03$ ) insulin release during the first phase of glucose-induced 

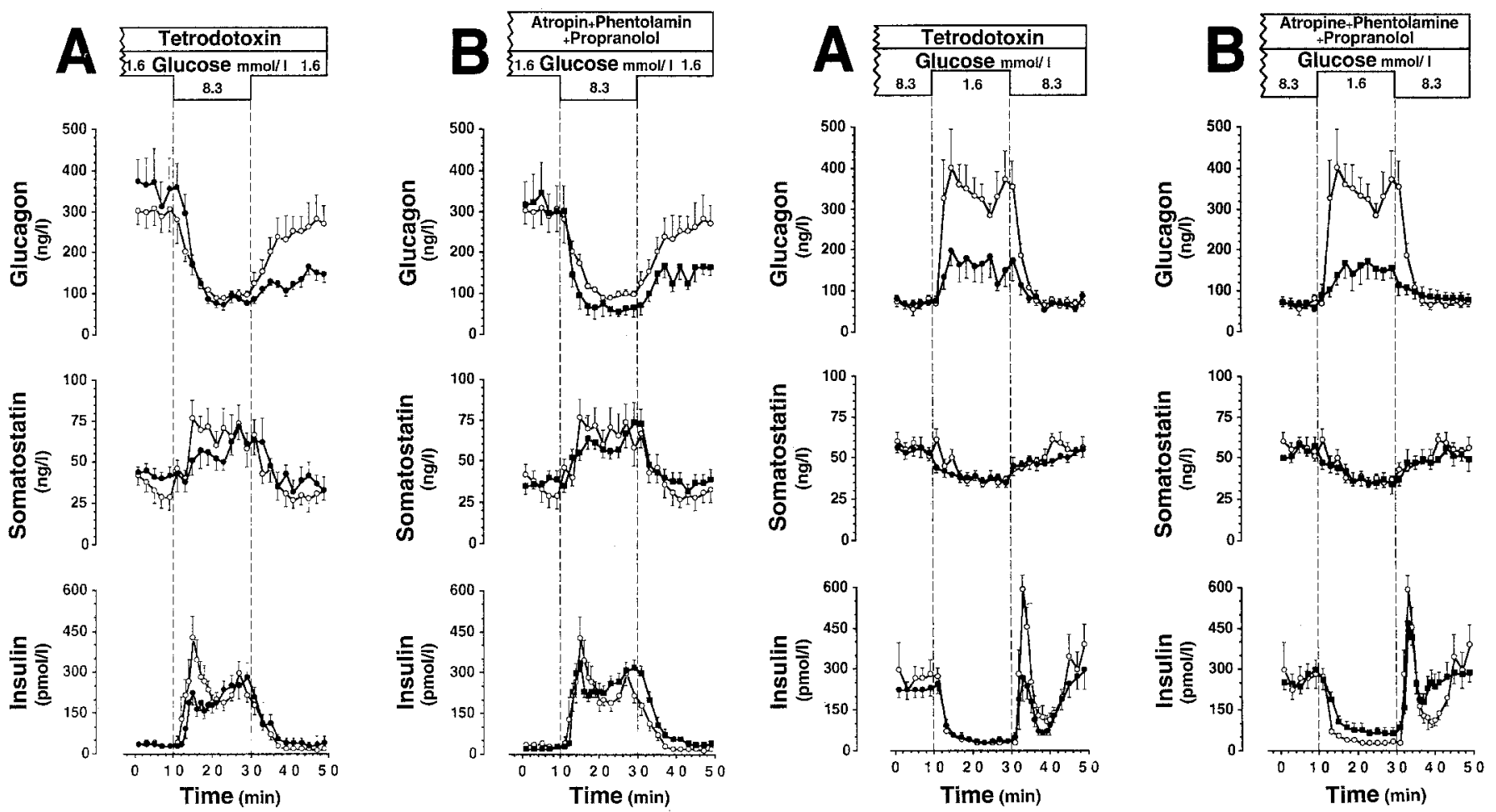

Fig. 1 A, B. Effect of $10^{-6} \mathrm{~mol} / \mathrm{l}$ tetrodotoxin $(\mathbf{A}, n=8, \rightarrow-)$ or combined adrenergic/cholinergic blockade with $10^{-5} \mathrm{~mol} / \mathrm{l}$ atropine, $10^{-5} \mathrm{~mol} / \mathrm{l}$ phentolamine and $10^{-5} \mathrm{~mol} / \mathrm{l}$ propranolol $(\mathbf{B}, n=9,-\mathbf{-})$ on insulin, somatostatin and glucagon secretion from the isolated perfused rat pancreas during perturbations of perfusate glucose levels from 1.6 to 8.3 and back to $1.6 \mathrm{mmol} / \mathrm{l}$. Control group with perfusion of glucose without the respective blocking agents $(n=8,0)$ (mean $\pm \mathrm{SEM}$ )

insulin secretion without affecting the second phase of stimulation. This effect of TTX upon the first phase of glucose-stimulated insulin release was comparable to the results shown in Figure $1 \mathrm{~A}$.

Somatostatin levels decreased by $21 \pm 5 \mathrm{ng} / \mathrm{l}(p<0.01)$ after reduction of perfusate glucose and returned to basal values during the following hyperglycaemia. In this experimental setting somatostatin secretion was not affected by TTX (Fig. 2A).

The decline in glucose concentration elicited a rise in mean glucagon levels from $70 \pm 11$ to $402 \pm 92 \mathrm{ng} / 1$ $(p<0.01)$. Glucagon levels remained elevated throughout the glucopenic period and returned promptly to baseline levels when the perfusate glucose concentration was restored to the initial value. TTX reduced the glucagon response to low perfusate glucose from $4620 \pm 695 \mathrm{ng} /$ $20 \mathrm{~min}$ in the control experiments to $1521 \pm 638 \mathrm{ng} / 20 \mathrm{~min}$ $(p<0.01)$.

\section{Effect of combined adrenergic and cholinergic blockade}

The combined blockade of adrenergic and cholinergic mechanisms by simultaneous infusion of atropine $\left(10^{-5} \mathrm{~mol} / \mathrm{l}\right)$, phentolamine $\left(10^{-5} \mathrm{~mol} / \mathrm{l}\right)$ and propranolol $\left(10^{-5} \mathrm{~mol} / \mathrm{l}\right)$ through the entire perfusion period did not modify glucose-induced secretion of insulin and somato-

Fig. 2 A, B. Effect of $10^{-6} \mathrm{~mol} / \mathrm{l}$ tetrodotoxin $(\mathbf{A}, n=8, \rightarrow--)$ or combined adrenergic/cholinergic blockade with $10^{-5} \mathrm{~mol} / \mathrm{l}$ atropine, $10^{-5} \mathrm{~mol} / \mathrm{l}$ phentolamine and $10^{-5} \mathrm{~mol} / \mathrm{l}$ propranolol $(\mathbf{B}, n=9,-\mathbf{-}-)$ on insulin, somatostatin and glucagon secretion from the isolated perfused rat pancreas during perturbations of perfusate glucose levels from 8.3 to 1.6 and back to $8.3 \mathrm{mmol} / \mathrm{l}$. Control group with perfusion of glucose without the respective blocking agents $(n=8,0)$ (mean \pm SEM)

statin (Fig.1B). The integrated first phase insulin response during TTX (2041 $\pm 304 \mathrm{pmol} / 10 \mathrm{~min})$ was also significantly lower than that during adrenergic and cholinergic blockade $(3164 \pm 362 \mathrm{pmol} / 10 \mathrm{~min} ; \quad p<0.05)$. Similar to the experiments with TTX the glucopenia-induced rebound of glucagon secretion was significantly reduced to $1392 \pm 178 \mathrm{ng} / 20 \mathrm{~min}(p<0.05)$ during adrenergic and cholinergic blockade. The magnitude of glucagon suppression by TTX and the combined adrenergic and cholinergic blockade showed no significant difference.

When perfusate glucose was decreased from initially 8.3 to $1.6 \mathrm{mmol} / \mathrm{l}$ the simultaneous infusion of atropine, phentolamine and propranolol did not alter the decrease and increase of insulin and somatostatin secretion following reduction and subsequent elevation of glucose levels, respectively (Fig. 2B). The integrated insulin release during the first $10 \mathrm{~min}$ after the rise of glucose in the presence of TTX was not only significantly lower compared to controls but also in comparison to the value during adrenergic and cholinergic blockade ( $1919 \pm 369$ vs $3388 \pm 246 \mathrm{pmol} /$ $10 \mathrm{~min} ; p<0.02$ ). The glucagon response to glucopenia, however, was significantly reduced to $30 \%$ of the control values by the adrenergic and cholinergic blockers $(1401 \pm 389 \mathrm{ng} / 20 \mathrm{~min}$ vs $4620 \pm 695 \mathrm{ng} / 20 \mathrm{~min} ; p<0.01)$. The reduction of the glucagon response to low perfusate glucose by atropine, phentolamine and propranolol and by TTX was nearly identical. 

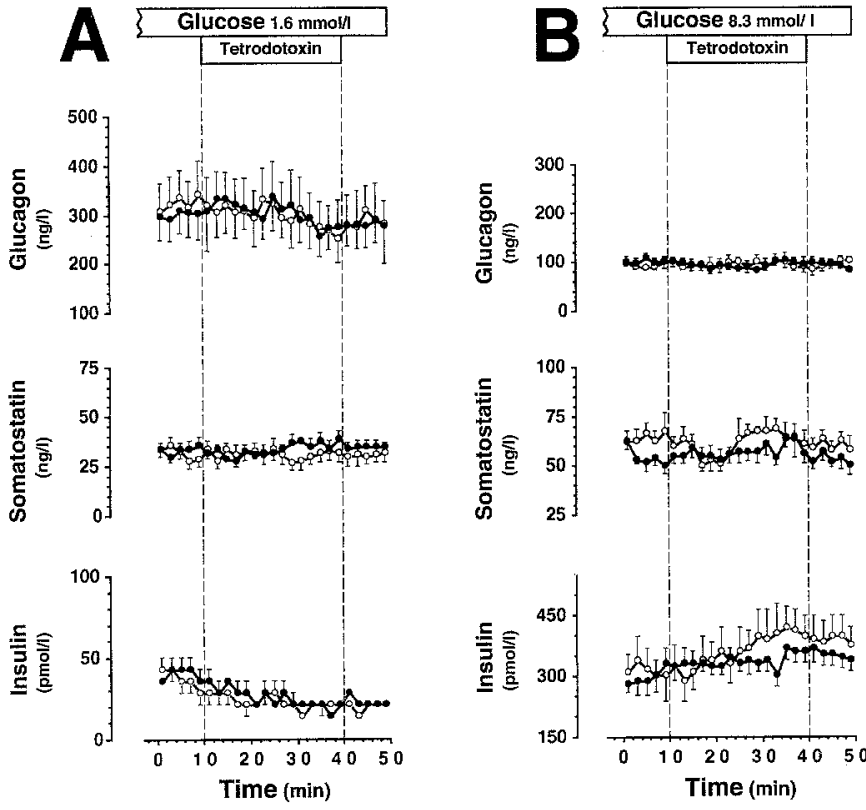

Fig.3A,B. Effect of $10^{-6} \mathrm{~mol} / 1$ tetrodotoxin ( - ) upon insulin, somatostatin and glucagon release from the isolated perfused rat pancreas during perfusion with a constant glucose concentration of $1.6 \mathrm{mmol} / 1(\mathbf{A}, n=8)$ or $8.3 \mathrm{mmol} / 1(\mathbf{B}, n=8)$, respectively. Control group with perfusion of glucose without tetrodotoxin $(n=7,0)$ (mean $\pm S E M)$
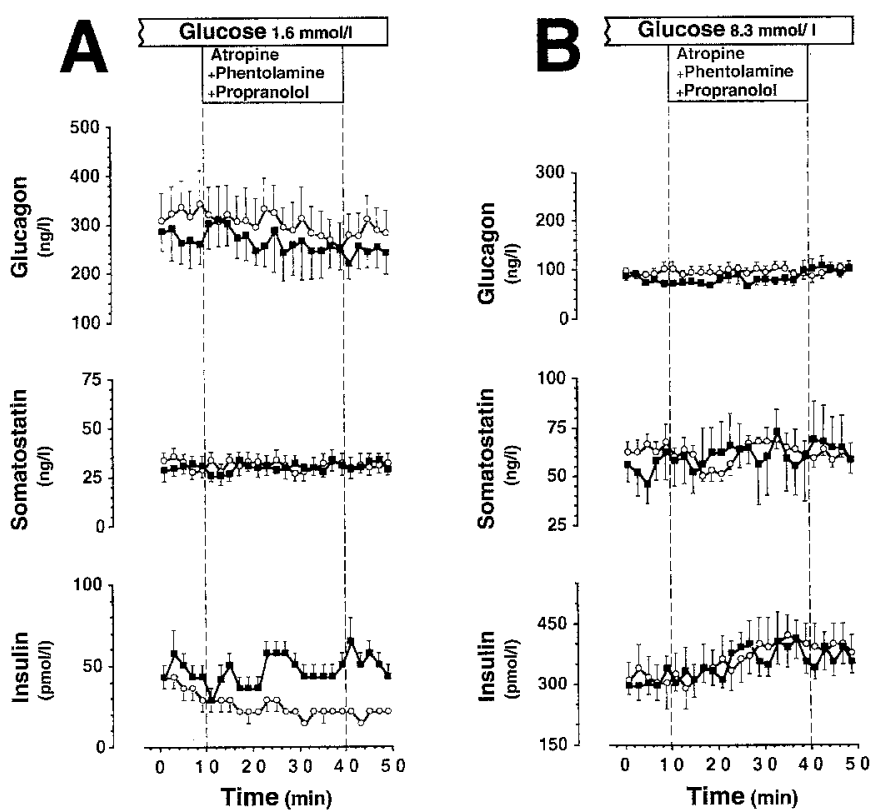

Fig.4A,B. Effect of combined adrenergic and cholinergic blockade $(\rightarrow-)$ with $10^{-5} \mathrm{~mol} / \mathrm{l}$ atropine, $10^{-5} \mathrm{~mol} / \mathrm{l}$ phentolamine and $10^{-5} \mathrm{~mol} / \mathrm{l}$ propranolol upon insulin, somatostatin and glucagon release from the isolated perfused rat pancreas during perfusion with a constant glucose concentration of $1.6 \mathrm{mmol} / \mathrm{I}(\mathbf{A}, n=8)$ or $8.3 \mathrm{mmol} / \mathrm{l}$ $(\mathbf{B}, n=8)$, respectively. Control group with perfusion of glucose without the respective blocking agents $(n=7,0)$ (mean \pm SEM)

In control experiments TTX (Fig.3) or the combined adrenergic and cholinergic blockade (Fig. 4) infused for $30 \mathrm{~min}$ had no effect on insulin, somatostatin and glucagon release during a constant glucose concentration of 1.6 or $8.3 \mathrm{mmol} / \mathrm{l}$, respectively.
To examine if similar effects of TTX can be observed at more physiological changes of perfusate glucose levels the first series of experiments was repeated with glucose levels increasing from 3.9 to $7.2 \mathrm{mmol} / 1$. This elevation of perfusate glucoseconcentration elicited asignificant rise in mean insulin levels from $43 \pm 7 \mathrm{pmol} / \mathrm{l}$ to $290 \pm 29 \mathrm{pmol} / \mathrm{l}$ in the first and $239 \pm 14 \mathrm{pmol} / \mathrm{l}$ in the second phase of stimulation as shown in Figure 5. As in the first series of experiments TTX (Fig. 5 A) reduced significantly the maximal $(290 \pm 29$ vs $166 \pm 51 \mathrm{pmol} / \mathrm{l}, p<0.03)$ and the integrated $(2440 \pm 138$ vs $1701 \pm 253 \mathrm{pmol} / 10 \mathrm{~min}, p<0.05$ ) insulin release during the first phase of glucose-induced insulin secretion without affecting the second phase of stimulation. The blockade of adrenergic and cholinergic mechanisms by simultaneous infusion of atropine, phentolamine and propranolol (Fig. 5B) was without effect on first and second phase insulin secretion also at these more physiological perturbations of perfusate glucose levels. There was also a significant difference between first phase insulin response during TTX and adrenergic/cholinergic blockade, respectively ( $1701 \pm 253$ vs $2744 \pm 210 \mathrm{pmol} / 10 \mathrm{~min} ; p<0.03$ ).

The increase of somatostatin secretion from $36 \pm 6 \mathrm{ng} / 1$ to $67 \pm 21 \mathrm{ng} / \mathrm{l}(p<0.05)$ following the elevation of glucose level from 3.9 to $7.2 \mathrm{mmol} / \mathrm{l}$ and the subsequent decrease of somatostatin release after reduction of glucose level to $3.9 \mathrm{mmol} / 1$ were attenuated neither by TTX (Fig. $5 \mathrm{~A}$ ) nor by adrenergic and cholinergic blockade (Fig. $5 \mathrm{~B}$ ).
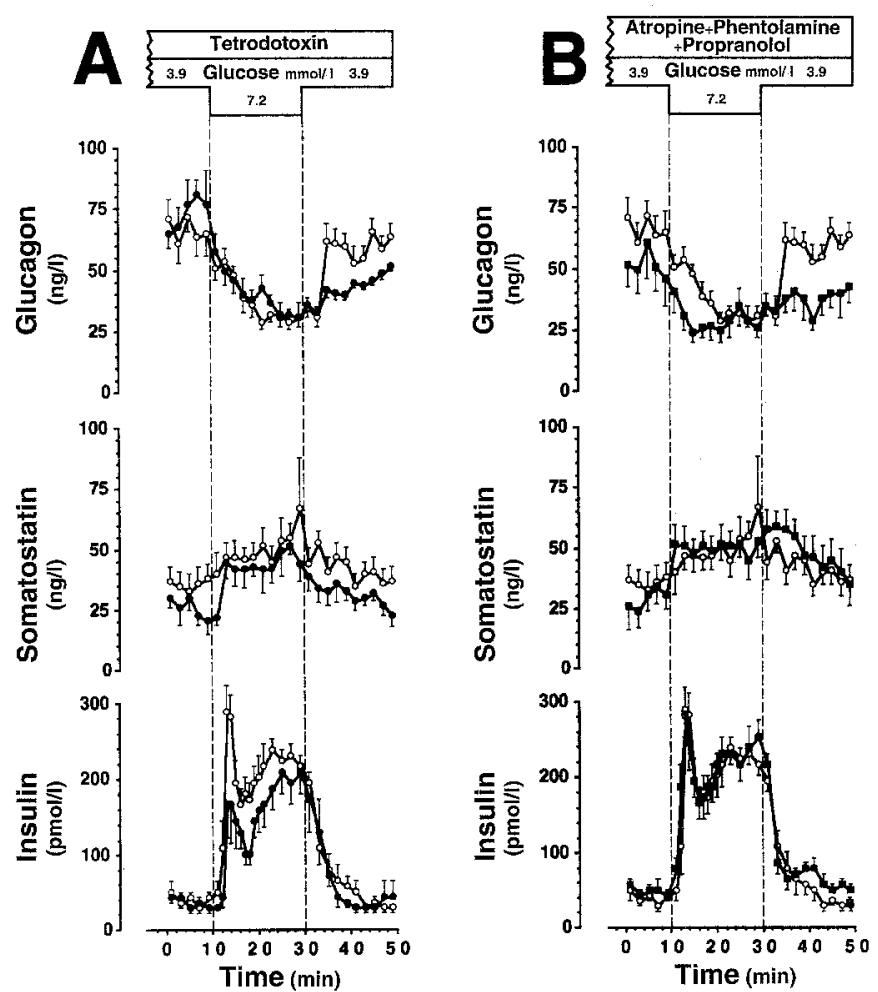

Fig.5A, B. Effect of $10^{-6} \mathrm{~mol} / 1$ tetrodotoxin $(\mathbf{A}, n=8,-\rightarrow)$ or combined adrenergic/cholinergic blockade with $10^{-5} \mathrm{~mol} / \mathrm{l}$ atropine, $10^{-5} \mathrm{~mol} / \mathrm{l}$ phentolamine and $10^{-5} \mathrm{~mol} / 1 \mathrm{l}$ propranolol $(\mathbf{B}, n=9,--)$ on insulin, somatostatin and glucagon secretion from the isolated perfused rat pancreas during more physiological perturbations of perfusate glucose from 3.9 to $7.2 \mathrm{mmol} / 1$ and back to $3.9 \mathrm{mmol} / 1$. Control group with perfusion of glucose without the respective blocking agents $(n=10,0)($ mean \pm SEM $)$ 


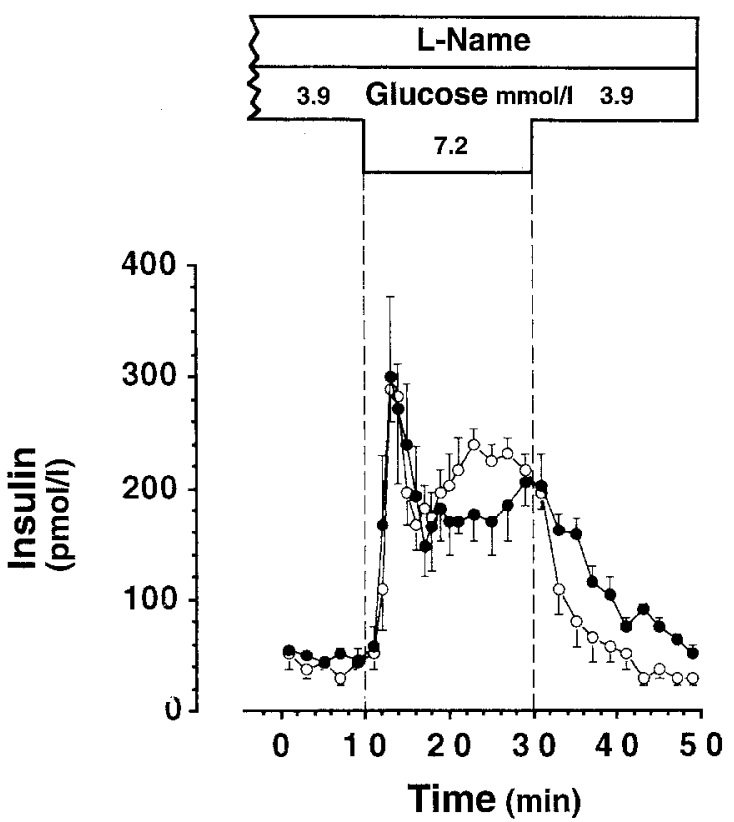

Fig.6. Effect of the nitric oxide synthase inhibitor $N^{G}$-nitro-L-arginine-methyl-ester (L-NAME, $10^{-4} \mathrm{~mol} / \mathrm{l}$ ) on insulin secretion from the isolated perfused rat pancreas during a change of perfusate glucose levels from 3.9 to $7.2 \mathrm{mmol} / \mathrm{l}$ and back to $3.9 \mathrm{mmol} / 1$. Control group $(n=10, O)$; L-NAME group $(n=5, \bullet)($ mean \pm SEM)

Glucagon secretion was suppressed from $72 \pm 6$ to $29 \pm 3 \mathrm{ng} / \mathrm{l}(p<0.01)$ by elevation of perfusate glucose concentration and it rose again to $64 \pm 9 \mathrm{ng} / \mathrm{l}$ when the glucose concentration was restored to $3.9 \mathrm{mmol} / \mathrm{l}$. This rebound secretion of $442 \pm 62 \mathrm{pg} / 20 \mathrm{~min}$ was significantly reduced by TTX $(140 \pm 33 \mathrm{pg} / 20 \mathrm{~min}, p<0.03$; Fig. $5 \mathrm{~A})$ and by combined adrenergic and cholinergic blockade $(156 \pm 96 \mathrm{pg} / 10 \mathrm{~min}, p<0.05$; Fig. $5 \mathrm{~B})$ similar to the first series of experiments.

In order to examine whether the foregoing non-cholinergic non-adrenergic effect might be mediated by nitric oxide, we tested the effect of L-NAME on insulin release. As shown in Figure 6 the addition of L-NAME to the perfusate had no significant effect on glucose-induced insulin secretion. During the first phase insulin rose to a maximum of $301 \pm 38 \mathrm{pmol} / \mathrm{l}$ in the presence of L-NAME compared to $290 \pm 29 \mathrm{pmol} / \mathrm{l}$ in controls (NS). The second phase rise was $206 \pm 21 \mathrm{pmol} / \mathrm{l}$ vs $239 \pm 14 \mathrm{pmol} / 1$ (NS), respectively. The integrated insulin response during the first phase was $2676 \pm 382$ vs $2440 \pm 138 \mathrm{pmol} / 10 \mathrm{~min}$ in the control group (NS).

\section{Discussion}

The isolated perfused pancreas has been separated from the extrinsic innervation and the remaining intrapancreatic neurons and ganglia are known to act independently $[4,5]$. Typical cholinergic and adrenergic $[2,7,9,10]$ as well as peptide containing nerves [12-20] have been observed in the islets, which might be regulators of islet cell function.

The puffer-fish poison TTX is unique in its selective blocking action on the increase of nerve membrane so- dium conductance, thereby preventing the propagation of action potentials. This effect is exerted at very low concentrations $\left(10^{-6}\right.$ to $\left.10^{-8} \mathrm{~mol} / \mathrm{l}\right)$ without any effect on other membrane parameters [21-23]. A comparison of TTX with other blocking agents specifically raises the possibility of differentiating between the action of classical neurotransmitters such as acetylcholine and catecholamines, on the one hand, and the non-cholinergic nonadrenergic system (NANC), on the other hand. The latter most likely represents the large group of peptidergic neurotransmitter candidates, although recent studies have provided evidence that nitric oxide should be considered as another candidate transmitter of NANC effects [3032].

The unchanged insulin, somatostatin and glucagon release in control experiments (constant glucose of 1.6 or $8.3 \mathrm{mmol} / \mathrm{l}$ ) demonstrates that TTX does not exert a toxic effect on the endocrine pancreas, and it suggests that neural mechanisms do not contribute to the secretion of the three islet hormones at constant glucose levels. This is in accordance with previous studies in isolated pancreatic islets [33-35]. On the other hand, phentolamine and propranolol when given separately raise basal insulin and somatostatin secretion in the rat pancreas [11], which is in contrast to the data of the present study. This difference cannot as yet be explained and requires further experimental work.

The insulin response to an increase and the glucagon response to a decrease of perfusate glucose levels was modified by TTX. The neurotoxin significantly reduces the first but not the second phase of glucose-induced insulin secretion. As TTX has no effect on glucose-induced insulin secretion from isolated islets [33-35], it appears likely that it reduces glucose-stimulated insulin release by blocking neural mechanisms. In line with this notion are the findings of Stagner and Samols [36] who demonstrated an effect of TTX of insulin oscillations in the perfused canine pancreas.

In contrast adrenergic and cholinergic antagonists had no influence on glucose-stimulated insulin secretion. The concentrations of the respective antagonists have previously been shown to be effective [37-40]. The lack of an effect of isolated or combined adrenergic and cholinergic blockade upon glucose-stimulated insulin release has been reported previously $[11,36]$. The difference between the effects of TTX and the combined adrenergic and cholinergic blockers upon the first phase insulin response suggests that NANC mechanisms contribute to first phase insulin secretion. NANC effects could be mediated either by neuropeptides or by nitric oxide. The latter substance, however, exerts an inhibitory effect in isolated islets [41] and it has no effect on insulin release from the perfused pancreas [41] which is in agreement with the present data.

Accordingly, intrapancreatic glucose-sensitive peptidergic neurons can contribute to the regulation of $\mathrm{B}$-cell function. From the candidate peptidergic neurotransmitters which are located in intrapancreatic nerves CCK [13], GRP [42], PHI [19] and VIP [43] can stimulate insulin secretion. NPY $[18,44]$, substance $P[45,46]$ and certain opioid peptides [47] have both stimulatory and inhibitory effects on insulin release, depending on the species exam- 
ined and the experimental conditions employed. The proof for a regulatory role of the endogenously released peptides awaits the development of potent and selective neuropeptide antagonists. In non-insulin-dependent diabetes mellitus the early postprandial insulin response is attenuated and the first pulse of insulin secretion after breakfast is delayed and of reduced amplitude [48]. An alteration of peptidergic neural factors could contribute to a reduced early insulin response according to the present data. This is supported by data from Giugliano et al. [49] who demonstrated an improvement of insulin secretion in non-insulin-dependent diabetic patients after administration of naloxone, a specific antagonist of endogenous opioid peptides.

The rise of glucagon during reduction of perfusate glucose was similarly attenuated by TTX or combined adrenergic/cholinergic blockade. In view of the virtually identical effects of phentolamine described by Hisatomi et al. [11], the rise of glucagon is most likely due to $\alpha$ adrenergic mechanisms without any additional cholinergic and peptidergic effects. The present data also suggest that the residual increase of glucagon which is still present during neural blockade might reflect a progressively reduced restraint of A-cell function by falling insulin levels rather than being mediated by any neural factors.

The present data confirm the previously reported direct stimulatory action of glucose upon pancreatic somatostatin secretion [50]. TTX or the combined adrenergic and cholinergic blockade had no consistent influence on somatostatin secretion. This suggests that neural mechanisms are presumably of only minor importance, if at all, for glucose-induced somatostatin release. It should be kept in mind though, that during other stimulatory conditions cholinergic and adrenergic mechanisms may very well contribute to pancreatic somatostatin release, as shown by several in vitro and in vivo studies $[6-8,37,39,40,51]$.

In conclusion the present data suggest that not only adrenergic intrapancreatic neurons but also peptidergic neurons are sensitive to changes in glucose concentration. The peptidergic neural mechanisms contribute to first phase insulin secretion but have no effect on glucose-induced alteration of glucagon and somatostatin release. The participating neuropeptides should be characterized when more specific blocking agents are available.

Acknowledgements. The authors thank K.Pfeiffer, B.Scheffer, S. Wiederer, and J.Zimmermann for expert technical assistance. The study was supported by DFG Schu 492-1/2, Leonhard-Lorenz-Stiftung, München, and Gesellschaft zur Förderung von Forschung und Lehre in der Inneren Medizin e. V.

\section{References}

1. Langerhans $P(1869)$ Contributions to the microscopic anatomy of the pancreas. MD thesis, Berlin (translated by Morrison $\mathrm{H}$, Johns Hopkins Hospital Press, Baltimore, 1937)

2. Tiscornia OM (1977) The neural control of exocrine and endocrine pancreas. Am J Gastroenterol 67: 541-560

3. Kamel I, Mikhail Y, Beshir S (1979) Study of the innervation of the pancreas of the rat. Acta Anat 104: 237-241

4. Brinn JE, Burden HW, Schweisthal MR (1977) Innervation of the cultured fetal rat pancreas. Cell Tiss Res 182: 133-138
5. Honjin R (1956) The innervation of the pancreas of mouse with special reference to the structure of the peripheral extension of the vegetative nervous system. J Comp Neurol 104:331

6. Ahren B, Taborsky GJ Jr, Porte D (1986) Neuropeptidergic versus cholinergic and adrenergic regulation of islet hormone secretion. Diabetologia 29: 827-836

7. Miller RE (1981) Pancreatic neuroendocrinology: peripheral neural mechanisms in the regulation of the islets of Langerhans. Endocrine Rev 2: 471-494

8. Smith PH, Madson KL (1981) Interactions between autonomic nerves and endocrine cells of the gastroenteropancreatic system. Diabetologia 20: $314-324$

9. Smith PH, Porte DJ (1976) Neuropharmacology of the pancreatic islets. Annu Rev Pharmacol Toxicol 16: 269-285

10. Woods SC, Porte D (1974) Neural control of the endocrine pancreas. Physiol Rev 54:596-619

11. Hisatomi A, Maruyama H, Orci L, Vasko M, Unger RH (1985) Adrenergically mediated intrapancreatic control of the glucagon response to glucopenia in the isolated rat pancreas. J Clin Invest $75: 420-426$

12. Larsson L-I (1979) Innervation of the pancreas by substance $\mathrm{P}$, enkephalin, vasoactive intestinal polypeptide and gastrin/ CCK immunoreactive nerves. J Histochem Cytochem 27: 12831284

13. Rehfeld JF, Larsson L-I, Goltermann NR et al. (1980) Neural regulation of pancreatic hormone secretion by the C-terminal tetrapeptide of CCK. Nature 284: 33-38

14. Pettersson M, Ahren B, Böttcher G, Sundler F (1986) Calcitonin gene-related peptide: occurrence in pancreatic islets in the mouse and the rat and inhibition of insulin secretion in the mouse. Endocrinology 119:865-869

15. Shimosegawa T, Kobayashi S, Fujita T, Mochizuki T, Yanaihara C, Yanaihara N (1983) Nerve elements containing met-enkephalin-ARG-GLY-LEU-like immunoreactivity in canine pancreas - a histochemical study. Neurosci Lett 42:161-165

16. Dunning BE, Ahren B, Veith RC, Bottcher G, Sundler F, Taborsky GJ (1986) Galanin: a novel pancreatic neuropeptide. Am J Physiol 251: E127-E133

17. Moghimzadeh E, Ekman R, Hakanson R, Yanaihara N, Sundler $F(1983)$ Neuronal gastrin-releasing peptide in the mammalian gut and pancreas. Neuroscience 10: 553-563

18. Dunning BE, Ahren B, Bottcher G, Sundler F, Taborsky GJ (1987) The presence and actions of NPY in the canine endocrine pancreas. Regul Pept 18: 253-265

19. Holst JJ, Fahrenkrug J, Knuhtsen S et al. (1987) VIP and PHI in the pig pancreas: coexistence, corelease, and cooperative effects. Am J Physiol 252: G182-G189

20. Sharkey KA, Williams RG, Dockray GJ (1984) Sensory substance $\mathrm{P}$ innervation of the stomach and pancreas. Demonstration of capsaicin-sensitive sensory neurons in the rat by combined immunohistochemistry and retrograde tracing. Gastroenterology 87:914-921

21. Kao CY (1972) Pharmacology of tetrodotoxin and saxitoxin. Fed Proc 31: 1117-1123

22. Narahashi T (1972) Mechanism of action of tetrodotoxin and saxitoxin on excitable membranes. Fed Proc 31: 1124-1132

23. Ulbricht W (1981) Kinetics of drug action and equilibrium results at the node of Ranvier. Physiol Rev 61: 785-828

24. Sussman KE, Vaughan GD, Timmer RF (1966) An in vitro method for studying secretion in the perfused isolated rat pancreas. Metabolism 15: 466-476

25. Schmid R, Schusdziarra V, Aulehner R, Weigert N, Classen M. (1990) Comparison of GLP-1 (7-36amide) and GIP on release of somatostatin-like immunoreactivity and insulin from the isolated rat pancreas. Z Gastroenterol 28: 280-284

26. Allescher HD, Sattler D, Piller C, Schusdziarra V, Classen M (1992) Ascending neural pathways in the rat ileum in vitro effect of capsaicin and involvement of nitric oxide. Eur J Pharmacol 217: 153-162

27. Herbert V, Lau K-S, Gottlieb CW, Bleicher SJ (1965) Coated charcoal immunoassay of insulin. J Clin Endocr 25: 1375-1384 
28. Faloona GR, Unger RH (1974) Glucagon. In: Jaffe BM, Behrman HR (eds) Methods of hormone radioimmunoassay. Academic Press, New York, pp 317-330

29. Harris V, Conlon JM, Srikant CB et al. (1978) Measurement of somatostatin-like immunoreactivity in plasma. Clin Chim Acta 87:275-283

30. Gillespie JS, Martin W (1980) A smooth muscle inhibitory material from the bovine retractor penis and rat anococcygeus muscles. J Physiol 309: 55-64

31. Martin W, Smith JA, Lewis MJ, Henderson AH (1988) Evidence that inhibitory factor extracted from bovine retractor penis is nitrite, whose acid activated derivative is stabilized nitric oxide. Br J Pharmacol 93: 579-586

32. Hobbs AJ, Gibson A (1990) L-N $\mathrm{N}^{\mathrm{G}}$-nitro-arginine and its methyl ester are potent inhibitors of non-adrenergic, non-cholinergic transmission in the rat anococcygeus. Br J Pharmacol 100: 749752

33. Milner RDG, Hales CN (1969) The interaction of various inhibitors and stimuli of insulin release studied with rabbit pancreas in vitro. Biochem J 113: 473-479

34. Pace CS (1979) Activation of Na channels in islet cells: metabolic and secretory effects. Am J Physiol 6: E130-E135

35. Pace CS, Blaustein MP (1979) Effects of neurotoxins on pancreatic islets. Elucidation of a possible role for sodium channels in the secretory response. Biochim Biophys Acta 585: 100-106

36. Stagner JI, Samols E (1985) Role of intrapancreatic ganglia in regulation of periodic insular secretions. Am J Physiol 248E522-E530

37. Samols E, Weir GC (1979) Adrenergic modulation of pancreatic A, B and D-cells. J Clin Invest 63: 230-238

38. Iversen J (1973) Adrenergic receptors and the secretion of glucagon and insulin from the isolated, perfused canine pancreas. J Clin Invest 52: 2102-2116

39. Holst JJ, Jensen SL, Knuhtsen S, Nielsen OV (1983) Autonomic nervous control of pancreatic somatostatin secretion. Am J Physiol 245: E542-E548

40. Holst JJ, Schwartz TW, Knuhtsen S, Jensen SL, Nielsen OV (1986) Autonomic nervous control of the endocrine secretion from the isolated, perfused pig pancreas. J Auton Nerv Syst 17: $71-84$

41. Jansson L, Sandler S (1991) The nitric oxide synthase II inhibitor $\mathrm{N}^{G}$-nitro-L-arginine stimulates pancreatic islet insulin release in vitro, but not in the perfused pancreas. Endocrinology 128:30813085
42. Bloom SR, Edwards AV, Ghatei MA (1983) Endocrine responses to exogenous bombesin and gastrin releasing peptide in conscious calves. J Physiol 344: 37-48

43. Jensen SL, Fahrenkrug J, Holst JJ, Nielsen OV, Schaffalitzky de Muckadell OB (1978) Secretory effects of VIP on isolated perfused porcine pancreas. Am J Physiol 235; E387-E391

44. Alwmark A, Ahren B (1987) Phentolamine reverses NPY-induced inhibition of insulin secretion in isolated rat islets. Eur $\mathbf{J}$ Pharmacol 135: 307-311

45. Brown M, Vale W (1976) Effects of neurotensin and substance $P$ on plasma insulin, glucagon and glucose levels. Endocrinology 98: 819-822

46. Hermansen K (1980) Effects of substance P and other peptides on the release of somatostatin, insulin and glucagon in vitro. Endocrinology 107: 256-261

47. Schick R, Schusdziarra V (1985) Physiological, pathophysiological and pharmacological aspects of exogenous and endogenous opiates. Clin Physiol Biochem 3: 43-60

48. Polonsky KS (1988) The kinetics of insulin, C-peptide, and proinsulin in normal and diabetic man. In: Creutzfeldt W, Lefèbvre P (eds) Diabetes mellitus: pathophysiologie and therapy. Springer-Verlag, Edinburgh

49. Giugliano D, Ceriello A, Di Pinto P, Saccomanno F, Gentile S, Cappiapuoti F (1982) Impaired insulin secretion in human diabetes mellitus. The effect of naloxone-induced opiate receptor blockade. Diabetes 31: 367-370

50. Ipp E, Dobbs RE, Arimura A, Vale W, Harris V, Unger RH (1977) Release of immunoreactive somatostatin from the pancreas in response to glucose, amino acids, pancreozymin-cholecystokinin, and tolbutamide. J Clin Invest 60: 760-765

51. Samols E, Stagner JI, Weir GC (1981) Autonomic function and control of pancreatic somatostatin. Diabetologia 30: 388-392

Received: 15 June 1992

and in revised form: 17 August 1992

Prof. Dr. V.Schusdziarra

Department of Internal Medicine II

Technical University of Munich

Ismaninger Straße 22

W-8000 München 80

FRG 